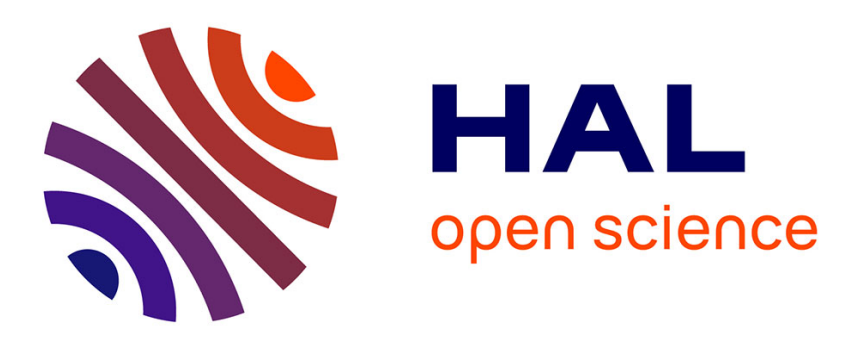

\title{
Objectives' alignment between members and agricultural cooperatives
}

François Bareille, Florence Beaugrand, Sabine Duvaleix-Treguer

\section{To cite this version:}

François Bareille, Florence Beaugrand, Sabine Duvaleix-Treguer. Objectives' alignment between members and agricultural cooperatives. Review of Agricultural, Food and Environmental Studies, 2017, 98 (1-2), pp.75-91. 10.1007/s41130-017-0048-3 . hal-01615938

\section{HAL Id: hal-01615938 \\ https://hal.science/hal-01615938}

Submitted on 19 Jan 2021

HAL is a multi-disciplinary open access archive for the deposit and dissemination of scientific research documents, whether they are published or not. The documents may come from teaching and research institutions in France or abroad, or from public or private research centers.
L'archive ouverte pluridisciplinaire HAL, est destinée au dépôt et à la diffusion de documents scientifiques de niveau recherche, publiés ou non, émanant des établissements d'enseignement et de recherche français ou étrangers, des laboratoires publics ou privés. 


\title{
Objectives' alignment between members and agricultural cooperatives
}

\author{
François Bareille $^{1}$ - Florence Bonnet-Beaugrand ${ }^{2}$. \\ Sabine Duvaleix-Tréguer ${ }^{1}$ (D)
}

Received: 26 January 2017 / Accepted: 19 May 2017 / Published online: 19 July 2017 (C) INRA and Springer-Verlag France 2017

\begin{abstract}
Members' commitment lessens when agricultural cooperatives grow larger. Their organization becomes more complex, and their membership more heterogeneous, which threatens their sustainability and leads them to implement specific mechanisms for collective decisions. We explore how the alignment of objectives between a multipurpose cooperative and its members influences member commitment. We estimate a multinomial probit model on a cross-section sample of 3205 members from a large agricultural cooperative in France. We assess the determinants of member commitment through four factors: the offer of new agricultural practices, the availability of outlets and supplies to members, the farm distance to the cooperative headquarters and the farm governance. We show that the adoption of new agricultural practices has a small but significant effect. The availability of outlets and supplies has the strongest effect on the economic involvement of the farmers. Other determinants, such as farm governance or geographical distance to the cooperative headquarters, also reinforce member commitment.
\end{abstract}

Keywords Agricultural cooperatives · Member commitment · Farm innovation · Economic involvement

JEL classifications Q13 $\cdot$ C35

Electronic supplementary material The online version of this article (doi:10.1007/s41130-017-0048-3) contains supplementary material, which is available to authorized users.

Sabine Duvaleix-Tréguer

sabine.treguer@agrocampus-ouest.fr

1 SMART-LERECO, AGROCAMPUS OUEST, INRA, 35000 Rennes, France

2 BIOEPAR, INRA, ONIRIS, 44000 Nantes, France 


\section{Introduction}

The role of agricultural cooperatives is often highlighted in a context of crisis as a way to better balance bargaining power in the agri-food chain. Farmers can either better negotiate prices and quantities in the market through producer organizations (horizontal concentration) or form marketing cooperatives to benefit from scale economies and to add value to their members' raw product through innovation and product quality (vertical organization) (Sexton and Lavoie 2001). To succeed and to meet these goals, agricultural cooperatives need to strengthen their relationships with their members. However, this can be challenging when they grow larger and become more complex organizations (Nilsson et al. 2009). Indeed, large agricultural cooperatives face a heterogeneous membership, which leads them to implement specific mechanisms for collective decisions that can substantially increase costs. They often use the "one member, one vote" principle as a voting scheme. However, because the median member preferences may not coincide with the mean member preferences, a majority voting scheme might lead to inefficient decisions because the cooperative strategy is not supported by the entire membership. This issue can be exacerbated when some members combine to influence decisions in favour of their own interest (Hansmann 1988). As a consequence, investor-owned firms (IOFs) can prove to be a more efficient organizational structure when membership is heterogeneous (Hart and Moore 1996) or when managerial vision bias is strong (Deng and Hendrikse 2015). Bontems and Fulton (2009) reinforce this result by showing that the cooperative organizational form is only efficient when the members' goals are aligned and there is no aversion to unequal income redistribution. The objectives' alignment between members and the cooperative reduces informational costs whereas an IOF faces them when it extracts rents from its suppliers. The main issue for cooperatives is to be able to differentiate themselves from IOFs and value membership commitment as argued by Fulton (1999, p.418): "member commitment is critical because it is a measure of how well a co-op is able to differentiate itself from an investor-owned firm". It is thus crucial to focus on member commitment and determine which factors reinforce it. We question how the alignment of the objectives of both members and the cooperative influence member commitment. We define here goal alignment as the association of the farmer's choices with the cooperative's strategies. This alignment might influence how a member participates in the cooperative and increases his commitment.

The aim of this study is to assess the determinants of member commitment. Because we choose to examine the links between members and their cooperative, we use unique datasets from a large multipurpose cooperative in France. This allows us to confront our results based on farmers' choices to the results found in the studies that explore attitudinal determinants (Hakelius and Hansson 2016; Barraud-Didier et al. 2014; Hernandez-Espallardo et al. 2013; Österberg and Nilsson 2009). Furthermore, we explore and discuss how innovation can be used as a specific instrument to align the objectives between the cooperative and its members. Innovation promotion can be a key strategy for agricultural cooperatives. In our case study, the cooperative has recently implemented a new leading strategy based on innovative environmentally friendly farm practices to meet members' demand. As a consequence, the cooperative differentiates itself from its competitors in both the upstream and the downstream markets. The CEO and the board of directors expect not only to gain market shares 
through the development of a new brand but also to commit their membership. The spread of innovative practices would then represent the best illustration of a goal alignment between members and the cooperative. We find that the availability of outlets and supplies has the strongest effect on the economic involvement of the farmers. We also show that farm innovation has a small but significant effect. The adoption of new agricultural practices reinforces the choice of high economic involvement.

In the following section, we present a literature review covering the key determinants of membership commitment and our hypotheses about goal alignment. Next, we describe our empirical model. In "Results" section, we present our results, and we discuss them in "Discussion" section. "Conclusion" section concludes.

\section{Determinants of member commitment}

\section{Related literature}

Member commitment includes two dimensions (Barraud-Didier et al. 2014; Österberg and Nilsson 2009; Trechter et al. 2002; Fulton 1999). First, members can be more or less economically involved, as they may not deliver all their products to the cooperative. We will refer to this dimension later on using the term "economic involvement". Second, they may not always strongly participate in cooperative governance (annual meeting attendance and voting participation). Both dimensions may affect cooperative performance.

As membership becomes more heterogeneous and as cooperatives depart from their founding project, member commitment decreases (Nilsson et al. 2009). This decline may then lead to a loss in competitiveness as agricultural cooperatives might lose market share. These market losses affect members' satisfaction because input prices are no longer low enough or output prices are not high enough. Hernandez-Espallardo et al. (2013) found empirically that the price paid to farmers determined their satisfaction with the cooperative and their intention to continue their membership. Because members' economic involvement affects the level of business sales each year, it is thus a critical issue for cooperatives and their members. High economic involvement increases the cooperative's benefits and allows investment or higher returns to members.

Hernandez-Espallardo et al. (2013) also showed that other determinants highlighted by the transaction cost theory (safeguarding, performance evaluation and adaptation) played an even more relevant role in explaining members' satisfaction with their cooperative and their desire to continue as members. First, members value all safeguarding measures, such as a secure outlet for their raw products in the short and long run. Second, members value their ability to get the information necessary to keep control over the board of directors. Third, members value the cooperative's services as it helps them to meet market requirements and better face societal evolution, for example, through the use of more environmentally friendly farm practices. The adoption of new agricultural practices may not only favour new practices in accordance with public regulation, but they may also improve farm efficiency and create value at the downstream level. Moreover, it can increase member loyalty and play an important role by renewing the cooperative ethos. 
Several studies have examined the determinants of member commitment within the cooperative, either on economic involvement or governance participation (BarraudDidier et al. 2014; Cechin et al. 2013; Österberg and Nilsson 2009; Hansen et al. 2002). Barraud-Didier et al. (2014) showed that the two levels of commitment are not necessarily linked. Previous studies have examined how attitudinal determinants influence membership, and more specifically, they have emphasized the role of trust (Barraud-Didier et al. 2012; Nilsson et al. 2009; Österberg and Nilsson 2009; Morrow et al. 2004; Hansen et al. 2002). Indeed, Roe et al. (2004) found that farmers who state that trust in the contractor is important in starting a contractual relationship prefer cooperative forms. Among other key determinants, some of them are related to the characteristics of the cooperative, such as its size and complexity (Nilsson et al. 2009). Other determinants are associated with the characteristics of farms or farmers. Farm size has a positive impact on both participation in governance and economic involvement (Bhuyan 2007; Gray and Kraenzle 1998; Klein et al. 1997). Pozzobon and Zylbersztajn (2011) demonstrated that the distance between the farm and the cooperative headquarters negatively influences the level of participation in governance. Filippi (2014) showed that coupling geographical proximity and cooperative governance could enhance member commitment. Many studies have also paid attention to members' age because of potential intergenerational conflicts. Incumbent members may fear that new members may take advantage by free riding the existing investment made by the cooperative, and thus, the cooperative may underinvest (Rey and Tirole 2007). Österberg and Nilsson (2009) showed that a member's age is not correlated to any cooperative commitment. However, they also showed that older members might disagree with the implementation of new business practices in the cooperative. For Klein et al. (1997), older farmers tend to be more economically involved than younger ones. Trechter et al. (2002) found that member commitment diminishes with the level of education, which Bhuyan (2007) confirmed. However, they also indicated that when a cooperative provides education or when members serve or have served on the board of directors or cooperative committee, the level of member commitment is positively affected.

\section{Conceptual framework and hypotheses}

We focus on the determinants of member commitment and more specifically on the relationships between the farmers and their cooperative. We measure member commitment using members' economic involvement. Economic involvement is a ratio that compares the number of activities for which a member delivers an output to the cooperative with the number of activities for which the member could choose to deliver among all the outputs he/she produces in his/her farm. The cooperative uses this measure to favour the members who deliver all their outputs regardless of their volume of sales channelled through the cooperative. It reinforces the equality principle among members.

In Fig. 1, we represent how farms' objectives may coincide with the cooperative's objectives. First, some characteristics of both farms and the cooperative are long-term characteristics such as the farm and the cooperative localization and farm governance. Members and the board of directors cannot easily adjust them; however, they may affect their relationships. Second, farmers take short-term decisions that may also 


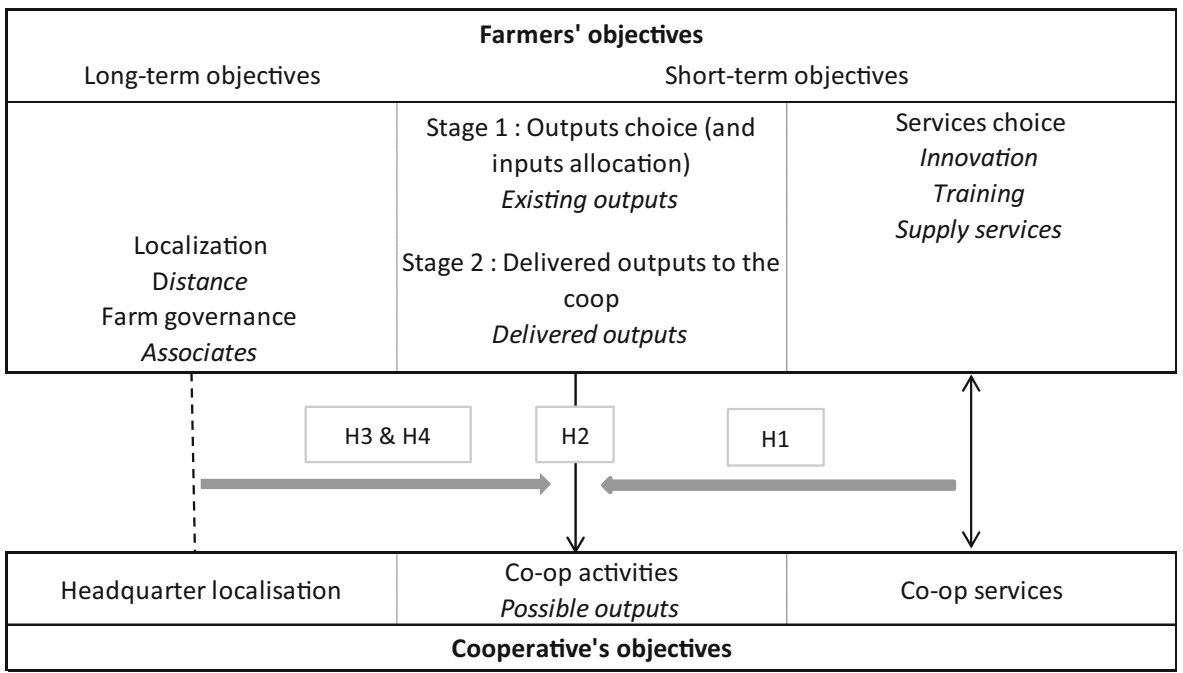

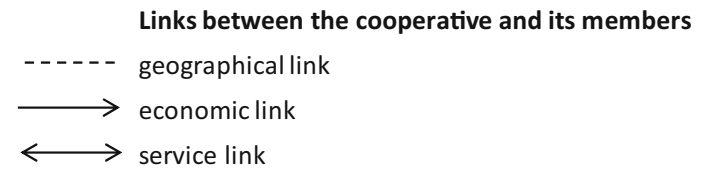

Note : in italics, we state the variable names

Fig. 1 Conceptual framework of objective alignment between the cooperative and its members

influence their economic involvement. They choose the outputs they produce, and then, they choose the processing firm. Finally, the cooperative may decide to provide some services, to which members can choose to subscribe. To examine the objectives' alignment, we formulate four hypotheses.

Hypothesis 1: Innovation strengthens economic involvement in the cooperative.

Innovation can play a specific role in aligning members' objectives with those of the cooperative. We intend to check whether, according to the results found by Klein et al. (1997), more innovation involves a higher observable farmers' commitment. The agricultural cooperative has invested in an R\&D department to develop new agricultural practices. We expect a higher commitment for members who adopt these techniques. First, the adoption of new agricultural practices can allow members to develop closer relationships with their field representatives who guide them towards technical changes (Filippi and Frey 2015). Thus, a member may feel more committed to the cooperative by subscribing to those services and may increase his/her economic participation. Second, the cooperative offers a "green" brand when its final products use raw agricultural material produced with, for example, low use of pesticides or antibiotics. By doing so, the cooperative vertically differentiates itself from its competitors in the downstream market and thus reduces price competition. The brand creates value-added that members can partially capture as they change their production 
system to more ecological practices. We assume that the subscription to those services leads to an increase in members' economic involvement. Farmers who do not use those practices cannot sell their products under the cooperative's green brand.

Hypothesis 2: The less the cooperative offers outlets and/or supplies, the less involved are the members.

The availability of outlets or supplies offered by the cooperative is another dimension of the alignment of objectives. The agricultural cooperative might choose to select its activities in each area, and thus, it might not provide all the outlets and supplies its members need. In the vicinity of the headquarters, the multipurpose cooperative offers a large choice of services. In the areas far from the headquarters, the cooperative might only keep the most profitable or the activities with the largest market shares. Therefore, members might be forced to diversify their suppliers or clients in those areas.

Hypothesis 3: The more distant the member is from the cooperative headquarters, the less involved he/she is.

Third, geographical distance can diminish membership participation (Pozzobon and Zylbersztajn 2011). Agricultural cooperatives, along with other agri-food firms, are merging and becoming larger companies. Their territorial area is thus wider. Member farms might then be located far away from the cooperative headquarters and might feel more distant from the decision-making.

Hypothesis 4: Farms run by several associates have a lower economic involvement in their cooperative.

Finally, farms face major structural changes. Not only are they growing larger, but most of them also have more than one manager because of the development of incorporated forms of legal organization. Each associate can thus develop his/her own competence and specialization on the farm. Fulton (1999) emphasized the role of ideology in sustaining membership commitment. However, the associates who own a farm might not all share the same preference for cooperative forms. Therefore, the farm associates may want to diversify their outlets in order to satisfy all of them. In addition, they might choose several clients and/or suppliers. For an agricultural cooperative, these changes in farm structure might lead to fewer committed members.

\section{Empirical model}

\section{Data}

Our study is based on a sample of 3205 members of a large French multipurpose cooperative located in Western France. A dataset involving more cooperatives could have been useful for the scope of the study, but an abundance of information would have been lost in the confidentiality compromise among cooperatives because of competition issues. Consequently, we have used a database with highly detailed 
members' information from one of the 5 largest agricultural cooperatives in France and among the 15 largest in the European Union. The cooperative is a multi-purpose cooperative whose sales were greater than 4 billion euros in 2013. The database provides information on various socioeconomic member attributes in 2013. The cooperative differentiates itself from other agricultural cooperatives by orienting its strategy towards farm innovation. Summary statistics are given in Table 1.

Economic involvement is measured using the ratio of delivered outputs to possible outputs. Delivered outputs represent the number of different activities for which a member delivers an output to the cooperative. Possible outputs denote the number of different activities for which a member could deliver an output to the multipurpose cooperative. Existing outputs denote the number of all the activities for which the member produces an output. Note that the number of existing activities is higher than the number of possible activities, which is higher than the number of activities that lead to delivered outputs. Economic involvement is based on the number of activities that each member undertakes with the cooperative, which means that this ratio does not capture any information on the farm's size or on member's sales generated with the cooperative. Furthermore, we examine only the active membership of the cooperative, which represents approximately $25 \%$ of all the farmers who are members of the co-op. The cooperative only collects extensive data on this group of members, which creates a selection bias. We test the effect of this bias on our results in Sect. 4. The cooperative defines an active member as a member whose economic involvement is greater than 0.5 . Active members represent approximately $60 \%$ of the total sales made by the members' activities. In our sample, the members of the cooperative produce 2.48 outputs on average and deliver 1.84 outputs to the cooperative.

Table 1 Summary statistics of the relationships between the cooperative and its members

\begin{tabular}{llllllll}
\hline$(N=3205)$ & Mean & Std dev & Min & Q1 & Median & Q3 & Max \\
\hline Economic involvement & 0.84 & 0.21 & 0.5 & 0.67 & 1 & 1 & 1 \\
Innovation (units) & 1.80 & 1.59 & 0 & 1 & 1 & 3 & 10 \\
Training & 0.01 & 0.12 & 0 & 0 & 0 & 0 & 1 \\
Supply services & 0.09 & 0.30 & 0 & 0 & 0 & 0 & 2 \\
Existing outputs (units) & 2.48 & 1.24 & 1 & 1 & 2 & 3 & 8 \\
Total Sales (1000 $€$ ) & 315 & 350 & 0 & 123 & 217 & 383 & 5399 \\
Territorial presence & 0.94 & 0.15 & 0.2 & 1 & 1 & 1 & 1 \\
Membership duration (years) & 17.27 & 10.71 & 0 & 7 & 17 & 25 & 64 \\
Distance (100 km) & 0.90 & 0.56 & 0.11 & 0.47 & 0.79 & 1.28 & 2.64 \\
County member density & 0.18 & 0.12 & 0.00 & 0.09 & 0.15 & 0.27 & 0.71 \\
Farm specialization & & & & & & 1 & 1 \\
$\quad$ Mixed farming & 0.59 & 0.49 & 0 & 0 & 1 & 1 & 1 \\
$\quad$ Specialization in crops & 0.33 & 0.47 & 0 & 0 & 0 & 1 & 1 \\
$\quad$ Specialization in animal production & 0.08 & 0.27 & 0 & 0 & 0 & 0 & 1 \\
Farm governance & & & & & & 1 & 1 \\
$\quad$ Sole owner & 0.31 & 0.46 & 0 & 0 & 0 & 1 & 1 \\
$\quad$ Associates & 0.69 & 0.46 & 0 & 0 & 1 & & 1 \\
\hline$\quad$ & & & & & & & 1 \\
\hline
\end{tabular}


Innovation relates to the number of new agricultural practices that members implement on their farm. The multipurpose cooperative offers 16 innovative agricultural practices, of which members implement 1.80, on average. The Supply services variable refers to the number of premium supply contracts that a member has subscribed to during the year. These contracts offer higher output prices as they allow the cooperative to make logistic efficiency gains. The cooperative offers two types of supply service contracts, but only $9 \%$ of members have subscribed to those supply services on average. Training refers to a 1-day training session for fuel-efficient agricultural machinery driving techniques. Only $1 \%$ of our sample attended this training session.

We also take into account the sales each member generates with the cooperative (Total sales). These sales represent 315,440 euros, on average. Territorial presence denotes how well the cooperative is established in its territory. We measure it using the ratio of possible outputs to existing outputs. A ratio equal to one means that the cooperative offers all the activities the members need. As the ratio decreases, the cooperative develops few activities in its territory because it does not provide either enough outlets or enough input supplies to its members. On average, the ratio is 0.94 , which means that the cooperative offers most of the outlet or input supply members need. However, for $10 \%$ of the cooperative members, one third of their outputs cannot be delivered to the cooperative. Note that some members can have an economic involvement equal to one even if the territorial presence variable is lower than one. The reason is that the cooperative does not provide all the outlets they need for the products they have on their farm. We also include membership duration. However, this measure suffers from some bias, as a farmer becomes a new member when their farm changes its legal status (for example, by becoming larger through land purchase, a new activity or the entry of a new associate). This means that shorter membership durations may not always characterize new members. Distance is the distance between the farmstead and the cooperative headquarters. Members are located approximately $90 \mathrm{~km}$ from the cooperative headquarters. One quarter of the members have a farm that is located less than $47 \mathrm{~km}$ from the headquarters. We measure the density of farmers in each county where the cooperative conducts business. The county member density variable is a proxy to capture the social interactions between member and non-member farmers. We use the agricultural census of 2010 to construct it. It measures the ratio of the number of members over the number of censed farmers in 2010 by county. By doing so, we assume that the change in farm structures between 2010 and 2013 is not significant. In the county where the cooperative has the largest number of members, $71 \%$ of the farmers in the county are members of the cooperative.

We use dummies to control for farm specialization using specialization in animal production, specialization in crops and mixed farming. In our sample, more than half of the farms are mixed farms (59\%), and a third specializes in crops $(33 \%)$. Only $8 \%$ of the farms are specialized in animal production. We also control for the farm governance to consider that several associates may run a farm. The variable Sole owner means that the farmer is sole owner of his/her farm $(31 \%$ of members in our sample). The variable Associates refers to farms 
that are run by several associates who may be or may not be family members $(69 \%)$.

\section{The empirical model}

We examine what determines a member's choice about his/her economic involvement in the cooperative using a multinomial probit model (Greene 2003). A member's utility $U_{i j}$ that is associated with alternative $j$ when the member $i$ has a choice among $k$ alternatives is the sum of a deterministic component $V_{i j}$ that depends on the regressors $x_{i}\left(x_{i} \in X\right)$ and an unobserved random component $\varepsilon_{i j}$.

$$
U_{i j}=V_{i j}+\varepsilon_{i j}
$$

$x_{i}$ are case-specific regressors as $V_{i j}=x_{i} \beta_{j} . X$ is the variable ensemble including our interest variables (i.e. innovation and supply services) and control variables (e.g. distance, the number of existing outputs, the cooperative territorial presence and farm governance). The introduction of control variables captures a portion of the member population heterogeneity and reduces endogeneity issues. The use of the multinomial probit model allows us to ignore the assumption that the $\varepsilon_{i j}$ terms follow an independently and identically standard type 1 extreme value distribution. Here, we assume that $\varepsilon_{i j}$ follows a multivariate normal distribution.

Farmers have three economic involvement alternatives. First, they can choose low economic involvement (alternative 1), which means that the ratio of delivered outputs to the possible outputs is 0.5 . Their second alternative is an intermediate level of economic involvement; the ratio of delivered outputs to the existing outputs is between 0.5 and 1 , and their last alternative (alternative 3 ) is high economic involvement where the ratio of delivered outputs to the existing outputs is equal to 1 . We assume that farmers choose their economic involvement in order to maximize their utility $U_{i j}$. $U_{i j}$ is a function of profit and the utility derived from cooperative membership. We assume that farmers only maximize their utility on the three alternatives. In our sample, 608 farmers choose low economic involvement (alternative 1), 714 farmers choose an intermediate economic involvement (alternative 2) and the remaining farmers have high economic involvement (alternative 3 ). Note that we do not use a continuous variable for economic involvement as members tend to be at both extremes.

We observe the outcome $y_{i j}=j$ when the alternative $j$ gives the highest utility among all the alternatives. It follows that

$$
\begin{gathered}
\operatorname{Pr}\left(y_{i j}=j\right)=\operatorname{Pr}\left(U_{i j} \geq U_{i k}\right) \text {, for all } k \\
\text { where } 0 \leq \operatorname{Pr}\left(y_{i j}=j\right) \leq 1 \text { and } \sum_{j=1}^{3} \operatorname{Pr}\left(y_{i j}=j\right)=1 .
\end{gathered}
$$

The issue of economic involvement is analysed by likelihood maximization through a multinomial probit model. In a multinomial probit model, the probability of a member 
$i$ choosing an economic participation $j$ is given by

$$
p_{i j}=\int_{w=-x}^{\frac{U_{i j}-U_{i 1}}{\left(\sigma_{i j}^{2}+\sigma_{i 1}^{2}-2 \sigma_{i j 1}\right)^{\frac{1}{2}}}} \phi(w) \times \Phi\left[\frac{\left(U_{i j}-U_{i 1}\right)}{\left[\left(\sigma_{i j}^{2}+\sigma_{i 1}^{2}-2 \sigma_{i j 1}\right)\left(1-r_{i j}^{2}\right)\right]^{\frac{1}{2}}}-\frac{w r_{i j}}{\left(1-r_{i j}^{2}\right)^{\frac{1}{2}}}\right] d w
$$

where $j$ stands for the level of economic involvement (low, intermediate and high). The base outcome is when members choose low economic involvement $(j=1)$, rij represents the correlation between the $\varepsilon_{i j}$ difference function of $\sigma_{i k}$ and is a function of $\sigma_{i j}$ (where $\sigma_{i j}$ enter in the distribution of the $\varepsilon_{i j}$ ). Considering that there are three alternatives, we have $\operatorname{cov}\left(\begin{array}{l}\varepsilon_{i 1} \\ \varepsilon_{i 2} \\ \varepsilon_{i 3}\end{array}\right)=\left(\begin{array}{ccc}\sigma_{i 1}^{2} & & \\ \sigma_{i 12} & \sigma_{i 2}^{2} & \\ \sigma_{i 13} & \sigma_{i 23} & \sigma_{i 3}^{2}\end{array}\right)$. In our case, we can write, for example, $r_{i 2}=\left(\sigma_{i 2}^{2}-\sigma_{i 12}-\sigma_{i 23}+\sigma_{i 13}\right) /\left[\left(\sigma_{i 1}^{2}+\sigma_{i 2}^{2}-2 \sigma_{i 12}\right)\left(\sigma_{i 2}^{2}+\sigma_{i 3}^{2}-2 \sigma_{i 23}\right)\right]^{1 / 2}$. In addition, $\phi()$ and $\Phi()$ represent the normal density and distribution function.

We compute semi-elasticities for each regressor to assess the effects of a relative change in the $k^{\text {th }}$ regressor on the probability that alternative $j$ is the outcome.

\section{Results}

Using four multinomial probit models, we determine which factors influence the economic involvement of members. In model 1 , we measure only the effect of our interest variables (Innovation, Training, and Supply services). Models 2, 3 and 4 include additional control variables. In model 2, we include farm fixed effects (Farm specialization and Farm governance) whereas in model 3, we include fixed effects about the relationships between the cooperative and members (Total sales, Territorial presence, Membership duration, Distance and County member density). Model 4 integrates all fixed effects. The semi-elasticities $\left(E_{j k}\right)$ and marginal effects $\left(M_{j k}\right)$ computed for model 4 are given in Table 2. The estimated coefficients of the four models, with their significance levels, are given in Appendix 1 (Table 3).

We also run the estimations using three other methods to consider the drawbacks in the distribution of our explanatory variable. The first model allows us to analyse the ordered structure of the economic involvement variable (low, intermediate and high alternatives). We run an ordered probit using the high alternative as the reference in order to examine its effects on the parameters. Second, we explore the double censorship structure of economic involvement using a tobit model. Economic involvement is in the interval $[0.5,1]$. In our data, there exists a selection bias because the cooperative collects only data for active members, who get an economic involvement ratio greater than or equal to 0.5 . We obtain the greatest economic involvement value, which is equal to one (that is to say that members use the cooperative for all their output sales or input purchases) by construction. Finally, we also explore for unobserved drivers and interaction effects of economic involvement by running a spatial autoregressive model (SAR) with an ordered probit structure (LeSage and Pace 2009). Cooperative members 
Table 2 Average change in the probability of choosing a low, intermediate or high level of economic involvement (model $4-$ multinomial probit estimation)

\begin{tabular}{|c|c|c|c|}
\hline Economic involvement & Low & Intermediate & High \\
\hline \multicolumn{4}{|l|}{ Semi-elasticities } \\
\hline Innovation & $-0.009 * *$ & -0.003 & $0.013 * * *$ \\
\hline Training & -0.021 & -0.024 & 0.045 \\
\hline Supply services & $-0.185^{* * *}$ & -0.012 & $0.197 * * *$ \\
\hline Existing outputs & -0.008 & $0.116^{* * *}$ & $-0.108^{* * *}$ \\
\hline Total sales & $-0.202 * * *$ & -0.097 & $0.299 * * *$ \\
\hline Total sales ${ }^{2}$ & $0.061 * * *$ & -0.060 & -0.001 \\
\hline Territorial presence & 0.068 & $0.593 * * *$ & $-0.660 * * *$ \\
\hline Membership duration & $-0.004 * *$ & 0.003 & 0.002 \\
\hline Membership duration $^{2}$ & $0.000 * * *$ & -0.000 & -0.000 \\
\hline Distance & 0.048 & $0.100^{*}$ & $-0.148^{* * *}$ \\
\hline Distance $^{2}$ & 0.020 & $-0.105^{* * *}$ & $0.085^{* * *}$ \\
\hline County member density & 0.057 & -0.054 & -0.002 \\
\hline \multicolumn{4}{|l|}{ Marginal effects } \\
\hline \multicolumn{4}{|l|}{ Farm specialization } \\
\hline \multicolumn{4}{|l|}{ Ref: mixed farming } \\
\hline Specialization in crops & $-0.302 * * *$ & $-0.042 * *$ & $0.345^{* * *}$ \\
\hline Specialization in animal production & $-0.063^{* *}$ & $-0.065^{* *}$ & $0.128 * * *$ \\
\hline \multicolumn{4}{|l|}{ Farm governance } \\
\hline Ref: sole owner & Ref & Ref & Ref \\
\hline Associates & $0.049 * * *$ & 0.024 & $-0.074 * *$ \\
\hline
\end{tabular}

$*, * *, * * *$ Significance level at 10,5 and $1 \%$

may benefit from local interactions, which can enhance economic involvement in the cooperative. We examine whether the interactions do modify parameter estimations. We obtain similar results (significance and signs) in all the three models. The results are provided in Appendix 2 (Table 4).

\section{Innovation and member commitment}

Innovation is a leading strategy for the multipurpose cooperative. Consequently, when farmers choose to adopt new agricultural practices, their objectives are aligned with the cooperative ones (hypothesis H1). We intend to check whether, according to the results found by Klein et al. (1997), more innovation involves a higher observable farmers' commitment. We find that innovation plays a small but significant role in economic involvement. The adoption of new agricultural practices through the purchase of cooperative services increases the probability of choosing a high level of economic involvement $\left(E_{\text {innovation, } 3}=0.013\right.$ ) and decreases the probability of choosing a low level of economic involvement $\left(E_{\text {innovation }, 1}=-0.01\right)$. The results from the subsamples give some complementary insights into innovation (Appendices 3 and 4). We find that new agricultural practices contribute to increasing the level of economic 
involvement for the farms that produce both crops and animal productions. Innovation might then be a vector of the alignment of goals between the farm and the cooperative through closer relationships with the field representatives because for the cooperative, these farms could diversify more easily their partnership. Innovation does not play any role for the farms with a low cooperative territorial presence. Those farmers only benefit from a reduced choice among all the available new practices as the cooperative has already made a selection of outlets and supplies in those areas.

The training variable has no influence on the probability to choose one of the economic involvement alternatives. The supply services play a similar role as the innovation one. The subscription to a supply service linearly increases the probability to be in a higher economic involvement level $\left(E_{\text {supply services }, 3}=0.20\right)$. The subscription to a supply service decreases the probability to be in the lowest economic involvement level $\left(E_{\text {supply services }, 1}=-0.19\right)$. Indeed, farm innovation services allow the cooperative to differentiate itself from its main competitors through "greener" production. Farmers anticipate higher prices coupled with cost reduction to increase the farm margins. The expected effect for supply services on farm margins is similar: supply service subscribers increase their expected utility and could have incentives to increase their economic involvement in order to benefit from the entire potential of these services.

\section{Other determinants of member commitment}

We explore how the alignment of objectives between the cooperative and its members influences member commitment. The multipurpose cooperative might not offer all the marketing outlets or all the inputs members need, which can lead to a lower economic involvement (hypothesis H2). The variable Territorial presence captures this effect, and it appears to be the main determinant of the economic involvement in the cooperative. We find that when the cooperative increases the number of outlets and supplies available to its members (the variable Territorial presence increases from 0 to 1 ), the probability of a member choosing a high economic involvement significantly decreases ( $E_{\text {Territorial presence } 3}=-0.66$ ). This result might seem surprising and leads to the rejection of hypothesis $\mathrm{H} 2$; however, we suggest a possible explanation. When the cooperative is not well established in an area, the choice of being economically involved does not rely only on economic and rational criteria; cooperative ideology might then play an important role. In the core area of the multipurpose cooperative, a farmer may choose to become a member because the cooperative organization represents the dominant firm. However, these farmers might not share the cooperative ideology and values. In this situation, economic criteria might strongly influence their choice. Moreover, in the low cooperative territorial presence area, the cooperative may favour the most profitable outlets or the most efficient activities. Consequently, the cooperative is more appealing to those farmers.

Second, geographical distance can diminish membership commitment (hypothesis H3). Distance from the cooperative headquarters does not affect the probability of a member choosing a low level of economic involvement. The semi-elasticity of a change in distance on the probability that a member chooses low economic involvement $E_{\text {distance }, 1}$ is not significant. However, it affects the intermediate and high levels. As the dishtance between the farm and the cooperative increases, the probability of a member choosing an intermediate level of economic involvement increases but a 
decreasing rate $\left(E_{\text {distance }, 2}=0.10\right.$ and $\left.E_{\text {distance }^{2}, 2}=-0.11\right)$. Moreover, it is more likely that a member chooses a higher level of economic involvement when distance to the cooperative headquarters decreases $\left(E_{\text {distance }, 3}=-0.15\right.$ and $\left.E_{\text {distance }{ }^{2}, 3}=0.09\right)$.

Third, farms face major structural changes (hypothesis H4). There are many differences according to farm governance. Farms that involve several associates have a lower probability of choosing high economic involvement $\left(M E_{\text {associates }, 3}=-0.07\right)$ and a higher probability of choosing low economic involvement $\left(M E_{\text {associates }, 1}=0.05\right)$, compared with the farms run by a sole owner. Each associate can thus develop his/ her own competence and specialization on the farm. However, associates who own a farm might not all share the same preference for cooperative forms. Therefore, farm associates may want to diversify their outlets in order to satisfy all of them. In addition, they might choose several clients and/or suppliers. For an agricultural cooperative, these changes in farm structure might lead to fewer committed members.

The effect of county member density on member commitment is not significant. It seems that membership duration has a small positive effect on economic involvement. The probability of a member choosing a low level of economic involvement decreases with membership duration $\left(E_{\text {duration }, 1}=-0.004\right)$. This effect is particularly important for the first years of membership as indicated by the measures of the squared variable. It could suggest that new members choose to test the cooperative quality at the first stage with only a few activities and choose to increase their involvement latter on. This result could also reflect the preference of younger farms for market diversification. However, as our measure is imperfect and the effects are not highly significant, we should be careful with it.

In addition, several variables explore the effect of farm diversification on members' economic involvement. Farms can be multi-output oriented. We show that there is no linear effect of the multi-output orientation of members' farms on their economic involvement. The presence of multi-outputs increases the probability of a member choosing an intermediate level of economic involvement $\left(E_{\text {existing }, 2}=0.12\right)$ and decreases the probability of a member choosing a high level of economic involvement $\left(E_{\text {existing, } 3}=-0.11\right)$. Members are less likely to choose high economic involvement as multi-output orientation enhances the opportunity to diversify the members' marketing channels. However, farm specialization increases the probability of choosing a high level of economic commitment. The effect is greater when farms specialize in crop production.

\section{Sensitivity analysis}

Estimations with ordered probit, tobit and SAR ordered probit models give similar results as the ones provided by the multinomial probit model. All the variables display the same signs. The amplitudes of the effects are explained by the estimation procedure. The results with the SAR ordered probit model highlight that unobserved spatial heterogeneity plays a large role in the total variability of our sample. Its correction does not, however, modify the signs of our interest variables (Appendix 2, Table 4).

We also test the robustness of our results on two subsamples: the mixed farming sample and the low territorial presence one. We choose the first subsample to release the bias that almost mechanically leads the specialized farms to be at the highest economic involvement alternative. We choose the second subsample to test for the 
cooperative territorial presence. The selected sample faces a reduced choice in outlets and supplies. We define a low territorial presence when its value is lower than one. The descriptive statistics and the results of the multinomial probit estimations of the two subsamples are available in Appendices 3 and 4 (Tables 5, 6, 7, 8). The results on the mixed farming sample are similar to the ones obtained on the whole sample. It seems that our fixed effects for specialized farms capture the tendency to be more economically involved. The results based on the farms located where the cooperative is not well established are weaker. We do not find any effect of farm innovation on this subsample. Supply services increase economic involvement, but the effect is strongest for the intermediate level of economic involvement (although very close to the effects found for the high alternative). We do find a non-linear effect of distance on economic involvement, but the effect is only significant on the intermediate alternative. The farms that are located far from the headquarters have a higher probability to choose this category. The results on the influence of farm governance are similar to the ones found on the whole sample: the sole-owner farms are more economically involved. The weaker results on this subsample are not surprising because we estimate the multinomial probit on only $13.8 \%$ of the initial population. It does not seem that the cooperative presence significantly influences the effects of the other variables. Overall, our robustness checks validate the results obtained by the multinomial probit on the whole sample.

\section{Discussion}

This empirical study provides new insightful results. First, we focus on the relationships between the cooperative and its members, using original datasets from a large multipurpose cooperative. It allows us to obtain information on members' choices and to confront our results with those obtained through surveys. Second, the study provides promising results about how farm innovation can play a key role in aligning members' goals with the ones of the cooperative. These results may not only be of benefit to cooperative managers but also to policymakers. Indeed, in a context of environmental pressure, policymakers should help cooperatives to develop environmental solutions. As cooperatives have incentives to promote innovation to their membership, the effectiveness of environmental subsidies may be enhanced. To date, there has been little research examining the role played by farm innovation. Karantininis et al. (2010) showed that the organization of the agri-food industry (in terms of vertical integration and contractual arrangements) matters for innovation. Agricultural cooperatives are a specific coordination scheme and when they are involved in innovation, welfare can be improved. Giannakas and Fulton (2005) demonstrated that agricultural cooperatives increase the rate of innovation while reducing the price of agricultural inputs. Drivas and Giannakas $(2008,2010)$ also found a positive effect on innovation activity when cooperatives exist in the market. These two theoretical studies underline the role of cooperatives, compared to IOFs, in innovation in the market. Note, however, that market structure could be more diverse; for instance, Agbo et al. (2015) provide insightful results when members can also use direct selling. However, these authors did not examine how innovation affects membership commitment. Innovation can lead members to be more efficient and reduce their production cost. It can also provide 
higher quality in the market. Whereas Jardine et al. (2014) demonstrate that a marketing cooperative can provide higher quality, Pennerstorfer and Weiss (2013) highlight that free riding is a crucial issue for quality provision. They find that free riding on quality is strong in agricultural cooperatives. However, the magnitude of this effect depends on how individual quality in raw product affects the aggregated quality of the final product. To our knowledge, few studies have examined the interaction between economic involvement and innovation. Klein et al. (1997) showed that farmers who believed that cooperatives offered more innovative services were more economically involved in those cooperatives. Here, we highlight the role of farm innovation in strengthening member commitment; yet, we were only able to use cross-sectional data from 2013, as the new agricultural practices have only recently been implemented in the cooperative.

\section{Conclusion}

We examine the drivers of member commitment in a large multipurpose cooperative that faces heterogeneous membership to better understand the links between members and their cooperative. As the alignment of objectives is a key issue for cooperative efficiency, we examine four factors that may have an influence on member commitment. We find that a reduced choice of activities has a positive effect on member commitment. In addition, we show that the adoption of innovative agricultural practices plays a small but significant role in the level of members' economic commitment. It increases the probability of choosing a high level of economic involvement and decreases the probability of choosing a low level of economic involvement. Other determinants, such as farm governance, the distance to the cooperative headquarters, member sales with the cooperative and the multi-output farm strategy, have an effect on the level of member commitment. Among these determinants, only the multi-output farm strategy and the distance to the cooperative headquarters do not have a linear effect on economic involvement. Distance does not influence the probability of members choosing a low level of economic involvement whereas it does affect the probability of choosing a high or an intermediate level of economic involvement.

It would be interesting to examine in more depth how innovation can be a possible force for strengthening membership involvement. As innovation is a long-term strategy, it would be interesting to further investigate how farm innovation spreads among all the members and how it affects economic involvement over years using panel data.

\section{References}

Agbo, M., Rousselière, D., \& Salanié, J. (2015). Agricultural marketing cooperatives with direct selling: A cooperative-non-cooperative game. Journal of Economic Behavior \& Organization, 109, 56-71.

Barraud-Didier, V., Henninger, M. C., \& El Akremi, A. (2012). The relationship between members' trust and participation in the governance of cooperatives: The role of organizational commitment. International Food and Agribusiness Management Review, 15(1), 1-24. 
Barraud-Didier, V., Henninger, M.-C., \& Triboulet, P. (2014). La participation des adhérents dans leurs coopératives agricoles: une étude exploratoire du secteur céréalier français. Canadian Journal of Agricultural Economics, 62(1), 125-148.

Bhuyan, S. (2007). The "people" factor in cooperatives: An analysis of members' attitudes and behavior. Canadian Journal of Agricultural Economics, 55(3), 275-298.

Bontems, P., \& Fulton, M. (2009). Organizational structure, redistribution and the endogeneity of cost: Cooperatives, investor-owned firms and the cost of procurement. Journal of Economic Behavior \& Organization, 72(1), 322-343.

Cechin, A., Bijman, J., Pascucci, S., \& Omta, O. (2013). Decomposing the member relationship in agricultural cooperatives: Implications for commitment. Agribusiness, 29(1), 39-61.

Deng, W., \& Hendrikse, G. W. J. (2015). Managerial vision bias and cooperative governance. European Review of Agricultural Economics, 42(5), 797-828.

Drivas, K., \& Giannakas, K. (2008). Process innovation activity in a mixed oligopsony: The role of marketing cooperatives. Journal of Rural Cooperation, 36(2), 131-156.

Drivas, K., \& Giannakas, K. (2010). The effect of cooperatives on quality-enhancing innovation. Journal of Agricultural Economics, 61(2), 295-317.

Filippi, M. (2014). Using the regional advantage: French agricultural cooperatives' economic and governance tool. Annals of Public and Cooperative Economics, 85(4), 597-615.

Filippi, M., \& Frey, O. (2015). Le conseiller, une pièce maîtresse sur l'échiquier de la coopérative agricole. Revue d'Études en Agriculture et Environnement, 96(3), 439-466.

Fulton, M. (1999). Cooperatives and member commitment. The Finnish Jounal of Business Economics, 4, 418-437.

Giannakas, K., \& Fulton, M. (2005). Process innovation activity in a mixed oligopoly: The role of cooperatives. American Journal of Agricultural Economics, 87(2), 406-422.

Gray, T. W., \& Kraenzle, C. A. (1998). Member participation in agricultural cooperatives: A regression and scale analysis. Rural Business-Cooperative Service. Research report 165. Washington, D.C.: US Department of Agriculture, Rural Business-Cooperative Service.

Greene, W. H. (2003). Econometric analysis. Pearson Education India.

Hakelius, K., \& Hansson, H. (2016). Measuring changes in farmers' attitudes to agricultural cooperatives: Evidence from swedish agriculture 1993-2013. Agribusiness, 32(4), 531-546.

Hansen, M. H., Morrow Jr., J. L., \& Batista, J. C. (2002). The impact of trust on cooperative membership retention, performance, and satisfaction: An exploratory study. The International Food and Agribusiness Management Review, 5(1), 41-59.

Hansmann, H. (1988). Ownership of the firm. Journal of Law, Economics, \& Organization, 4(2), $267-304$.

Hart, O., \& Moore, J. (1996). The governance of exchanges: Members' cooperatives versus outside ownership. Oxford Review of Economic Policy, 12(4), 53-69.

Hernandez-Espallardo, M., Arcas-Lario, N., \& Marcos-Matas, G. (2013). Farmers' satisfaction and intention to continue membership in agricultural marketing co-operatives: Neoclassical versus transaction cost considerations. European Review of Agricultural Economics, 40(2), 239-260.

Jardine, S. L., Lin, C. C.-Y., \& Sanchirico, J. N. (2014). Measuring benefits from a marketing cooperative in the Copper River fishery. American Journal of Agricultural Economics, 96(4), 1084-1101.

Karantininis, K., Sauer, J., \& Furtan, W. H. (2010). Innovation and integration in the agri-food industry. Food Policy, 35(2), 112-120.

Klein, K., Richards, T., \& Walburger, A. (1997). Determinants of co-operative patronage in Alberta. Canadian Journal of Agricultural Economics, 45(2), 93-110.

LeSage, J. P., \& Pace, R. K. (2009). Introduction to spatial econometrics (Statistics, textbooks and monographs). CRC Press.

Morrow Jr., J. L., Hansen, M. H., \& Pearson, A. W. (2004). The cognitive and affective antecedents of general trust within cooperative organizations. Journal of Managerial Issues, 16(1), 48-64.

Nilsson, J., Kilhén, A., \& Norell, L. (2009). Are traditional cooperatives an endangered species? About shrinking satisfaction, involvement and trust. International Food and Agribusiness Management Review, 12(4), 101-122.

Österberg, P., \& Nilsson, J. (2009). Members' perception of their participation in the governance of cooperatives: The key to trust and commitment in agricultural cooperatives. Agribusiness, 25(2), 181197.

Pennerstorfer, D., \& Weiss, C. R. (2013). Product quality in the agri-food chain: Do cooperatives offer highquality wine? European Review of Agricultural Economics, 40(1), 143-162.

Pozzobon, D. M., \& Zylbersztajn, D. (2011). Member participation in cooperative governance: does heterogeneity matter? In $X X X V$ Encontrp da ANPAD. Rio de Janeiro, 17pp. 
Rey, P., \& Tirole, J. (2007). Financing and access in cooperatives. International Journal of Industrial Organization, 25(5), 1061-1088.

Roe, B., Sporleder, T. L., \& Belleville, B. (2004). Hog producer preferences for marketing contract attributes. American Journal of Agricultural Economics, 86(1), 115-123.

Sexton, R. J., \& Lavoie, N. (2001). Food processing and distribution: An industrial organization approach. Handbook of Agricultural Economics, 1, 863-932.

Trechter, D. D., King, R. P., \& Walsh, L. (2002). Using communications to influence member commitment in cooperatives. Journal of Cooperatives, 17, 14-32. 